\title{
Disruptive Impacts of Automated Driving Systems on the Built Environment and Land Use: An Urban Planner's Perspective
}

\author{
Tan Yigitcanlar ${ }^{1, *} \mathbb{\infty}$, Mark Wilson ${ }^{2} \mathbb{D}$ and Md Kamruzzaman ${ }^{3}$ \\ 1 School of Technology, Department of Knowledge Engineering, Federal University of Santa Catarina Campus \\ Universitário, Trindade, Florianópolis, Santa Catarina CEP 88040-900, Brazil \\ 2 School of Planning, Design and Construction, Michigan State University, 552 W. Circle Drive, East Lansing, \\ MI 48824, USA; wilsonmm@msu.edu \\ 3 Faculty of Art, Design and Architecture, Monash University, 900 Dandenong Road, Caulfield East, VIC 3145, \\ Australia; md.kamruzzaman@monash.edu \\ * Correspondence: tan.yigitcanlar@ufsc.br; Tel.: +61-3138-2418
}

Received: 27 March 2019; Accepted: 19 April 2019; Published: 24 April 2019

\begin{abstract}
Cities have started to restructure themselves into 'smart cities' to address the challenges of the 21st Century-such as climate change, sustainable development, and digital disruption. One of the major obstacles to success for a smart city is to tackle the mobility and accessibility issues via 'smart mobility' solutions. At the verge of the age of smart urbanism, autonomous vehicle technology is seen as an opportunity to realize the smart mobility vision of cities. However, this innovative technological advancement is also speculated to bring a major disruption in urban transport, land use, employment, parking, car ownership, infrastructure design, capital investment decisions, sustainability, mobility, and traffic safety. Despite the potential threats, urban planners and managers are not yet prepared to develop autonomous vehicle strategies for cities to deal with these threats. This is mainly due to a lack of knowledge on the social implications of autonomous capabilities and how exactly they will disrupt our cities. This viewpoint provides a snapshot of the current status of vehicle automation, the direction in which the field is moving forward, the potential impacts of systematic adoption of autonomous vehicles, and how urban planners can mitigate the built environment and land use disruption of autonomous vehicles.
\end{abstract}

Keywords: autonomous vehicle; autonomous driving; disruptive technology; land use change; built environment; smart city; smart urbanism; smart mobility; urban innovation; urban planning

\section{Introduction: Smart Cities, Smart Mobility, and Autonomous Vehicles}

We are at the verge of a new urban era-i.e., the age of smart urbanism [1-4]. Today, cities are integrating technological innovation in decision-making and service provision to address a range of challenges caused by urbanization-e.g., traffic congestion, greenhouse gas emissions, energy efficiency-under the smart city notion [5-7]. Technology, particularly in the name of smart urban mobility solutions, is becoming a key concept of the smart city movement and agenda to address the undesirable effects of transport [8-11].

A smart city represents enhanced access to sustainable modes of transport; leading to higher environmental and health standards and upgraded quality of life for all—including disadvantaged residents [12-14]. Smart mobility solutions can provide users with an increased number of options and offer more convenient, adaptable, and affordable journeys, while reducing dependence on private vehicle use as well as promoting energy efficient mobility [15-17]. Originally perceived within the smart cities agenda, according to Faisal et al. [18], the smart urban mobility concept is "characterized 
by an integration of sustainable and smart vehicular technologies, and cooperative intelligent transport systems through cloud-servers and big-data-based vehicular networks" (p. 46). In other words, it is an umbrella term for urban traffic services combined with smart technologies [19-21].

Falling under the smart mobility umbrella, 'autonomous vehicles' (AVs)—also referred to as driverless cars-are the products of autonomous driving technologies. AVs are considered one of the most innovative applications of technologies, within the broader smart transport agenda, of our time $[22,23]$. At the same time, AVs are widely argued to be one of the most disruptive technologies to fundamentally reshape our cities in the age of smart urbanism [24,25].

Although it has become highly popular during the smart city movement in recent years, the concept of AVs is not new. Vehicle automation was originally envisioned as early as 1918 [26]. However, only recent advancements in automated driving technology have made AVs commercially viable. In addition to enabling vehicles to drive autonomously, technology also allows vehicles to communicate with each other, infrastructure, and smart city management systems-so-called connected autonomous vehicles $(\mathrm{CAV})$. The resulting $\mathrm{AV}$, and $\mathrm{CAV}$, offers a wide-range of advantages as well as complications for urban life. On the one hand, for instance, the smart parking system of an AV in a smart city can have a beneficial effect on air pollution [27], or the new artificial intelligence-based solution called 'extreme learning machines', when integrated with AVs, can be useful in energy conservation or harvesting [28]. On the other hand, the lack of a clear AV legal framework in cities complicates wide-scale AV uptake and public perceptions towards them [29-31].

The challenge for communities and policymakers/decision-makers is that AVs have a wide-range of possible impacts, but the specific implications can vary by place depending on how they are implemented. Communities can choose how to introduce a new technology, and thereby shape its social impacts, or to accept what is seen as inevitable based on the interests influencing adoption. While AVs may be ready for road use, as put forward by Wilson [32] the important question here is whether our communities are ready to make decisions about this new technology.

The recent $\mathrm{AV}$ implementation predictions suggest that before the mid-century about half of private motor vehicles could be autonomous [33]. This prediction implies that AVs will be an almost as common part of life as present-day smart phones by 2050 — that is only three decades away (Figure 1). These vehicles are expected to include the following types of AV ridership: family AVs-vehicle owned and shared by a family; shared AVs (SAVs) - vehicle not owned, but used privately on demand; pooled-shared AVs - vehicle not owned, but used on demand with multiple riders simultaneously. Pooled/shared AVs will also be offered as part of an autonomous mobility-as-a-service solution.

Bloomberg [34] reported that thirty-six cities are currently trailing AVs on road or in a laboratory. In addition, eighteen cities are gathering data about institutional (regulation, planning, governance) constraints and opportunities associated with the trialing of AVs. Leading North American cities currently undergoing a transition to AVs include Austin, Las Vegas, Boston, Pittsburgh, Detroit, San Francisco, Toronto, and Washington DC. Likewise, Sydney, Melbourne, and Brisbane, from Australia, are the leading cities that are in the process of running $\mathrm{AV}$ trials and considering to formulize needed regulations. Various car and technology corporations are supporting the AV ambitions of these cities [35,36].

Until now, research has mainly focused on the technological advancement of AVs (Figure 2) and only a few studies have investigated the short-term transport effects of AVs- e.g., trip generation impacts [37]. However, little attention has been given to the long-term impacts of AVs-e.g., AV induced urban development patterns and landscapes (fragmentation) of our cities. The history of urbanization has shown that every advancement in transportation technology—from horse carts to Maglev—have greatly impacted the built environment, urban form, and social organization of our cities. It is, hence, expected that the introduction of AVs would change the way of utilizing and developing urban space dramatically [38]. However, the likely AV-induced changes in urban form and their rebound effects on mobility are understudied areas of research. In addition, the planning and regulatory context, plus the lack of scientific evidence leaves urban planners-along with legislators, urban managers, administrators, and policymakers - unprepared to deal with the possible spatial reorganization and social disruption of AVs. 


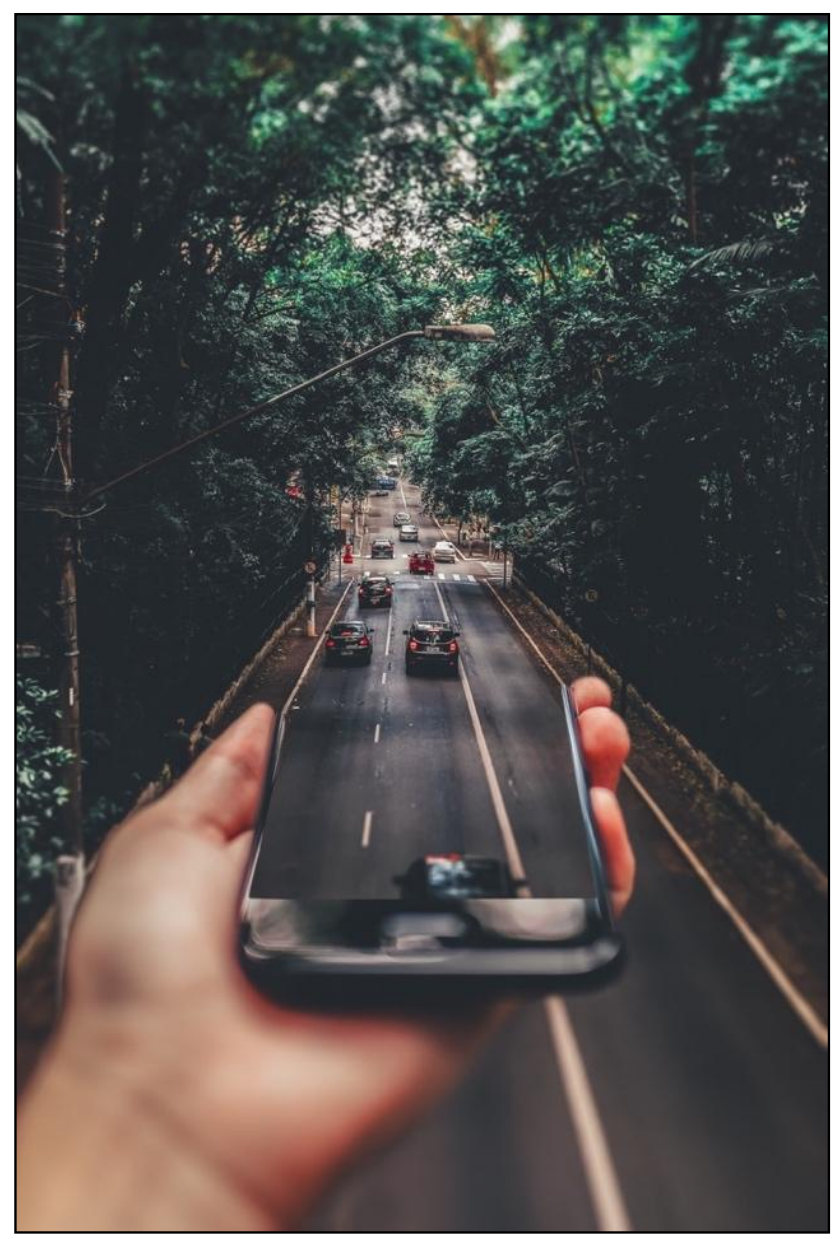

Figure 1. A metaphor for autonomous vehicles, 2019. A copyright free photo by Matheus Bertelli from Pexels, https://www.pexels.com/photo/forced-perspective-photography-of-cars-running-on-roadbelow-smartphone-799443.

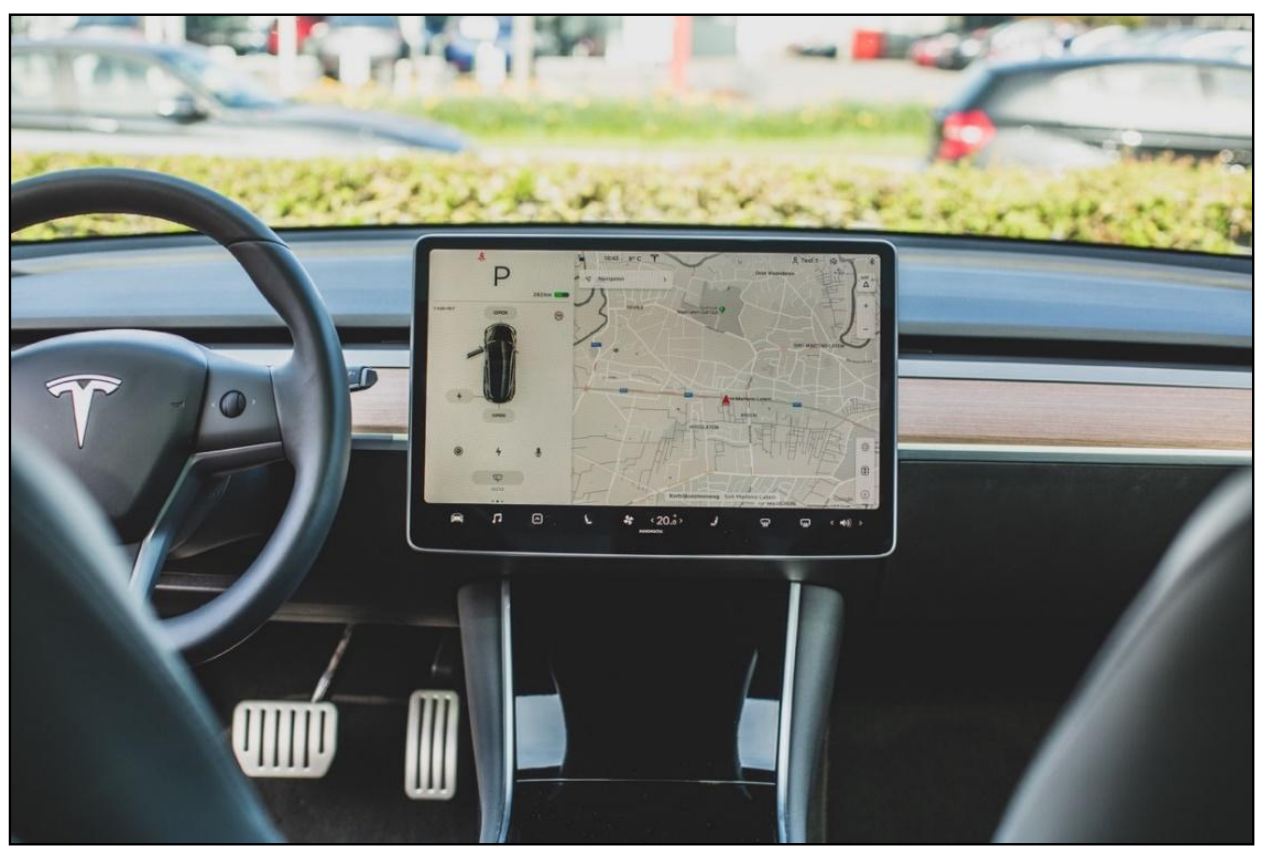

Figure 2. Navigator system control panel of an autonomous vehicle, 2019. A copyright free photo by Bram Van Oost from Unsplash, https://unsplash.com/photos/oOCI35aIA3M. 
Many scholars foresee that the widespread use of AVs will likely result in accident reduction, congestion improvement, flexibility of time spent travelling, and transport-related social inclusion [39-41]. Other scholars stay dubious about the outcome due to the restricted understanding of how AVs will work effectively inside the prior complicated transportation system [42]. Particularly, urban planners, in general, seem to be unprepared for the likely AV disruption on the built environment and land use of our cities.

Against this backdrop, this viewpoint aims to provide a snapshot of the current status of vehicle automation, the direction in which the field is moving forward, the potential impacts of systematic adoption of $\mathrm{AV}$, and how planners can mitigate the built environment and land use disruption of AVs in the age of smart urbanism and mobility. Note that, despite acknowledging the connected vehicle also as a disruptive technology [43], this viewpoint mainly focuses on AVs-assuming connected vehicle technology will be part of AVs in the future to form connected-AVs. In terms of the methodologic approach, this study conducts the following: (a) reviewing the literature focusing on the impacts of AVs on the built environment and land use; (b) providing a commentary on the key literature review findings, and; (c) speculating on how planners can mitigate the built environment and land use disruptions likely to be caused by a wider AV uptake.

\section{Background: Current State and Future Direction of Autonomous Vehicles}

AVs include automobiles, trucks, drones, ferries, and ships that are driverless or self-driving. Autonomous mobility has evolved incrementally over decades employing many different technologies for steering, navigation, collision avoidance, and maneuvering that will culminate in fully autonomous systems in the next few years. Some elements of AVs have been in use for many years while others are just entering the market. A further implication of the introduction of AVs depends on the power source used, with many AVs being electric (Figure 3) rather than gasoline/diesel, so a shift to AVs may also herald a shift in vehicle energy sources [44]. When summed, however, the set of technologies offers the potential for a vehicle to move and navigate through traffic with no driver assistance.

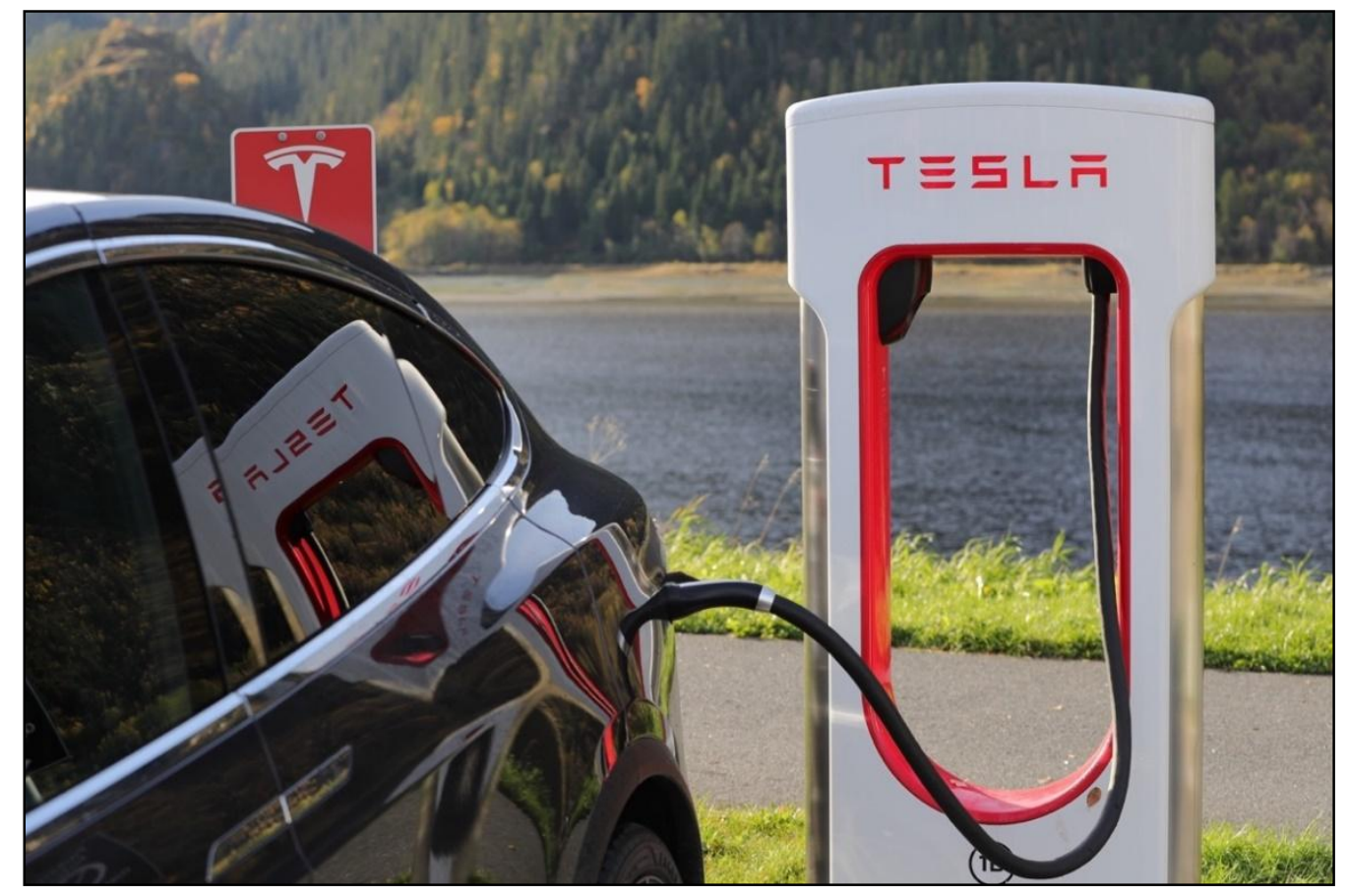

Figure 3. An electric autonomous vehicle charging, 2019. A copyright free photo by Blomst from Pixabay, https://pixabay.com/photos/tesla-tesla-model-x-charging-1738969. 
In analyzing the implications of AVs, it is important to recognize fundamental differences in design and use that will not allow vehicle trajectories, as we have known them to continue. The impact will depend on how AVs are used. A case where individuals own an AV and only use it for their household will lead to more travel as the vehicle returns home or to a holding area between uses. In contrast, a ride-sharing model could reduce pressure on parking and change land use. Certainly, ride-hailing applications such as Lyft and Uber have challenged prior norms and could provide some of the benefits of AVs if widely adopted [45].

There are various degrees of autonomy for motor vehicles. Table 1 shows the automation levels that have been introduced by the German Federal Highway Research Institute (BASt), the US National Highway Traffic Safety Administration, and the US Society of Automotive Engineers [46-48]. In these classifications, for levels zero to two the driver is in control and must constantly manage vehicle movement, with assistance on warnings, braking, parking, lane centering and adaptive cruise control. For the more advanced capabilities (levels three to five), the vehicle takes increasing control. For example, no action is needed by a human driver in level five autonomy. Currently, AVs in the US roads range between level two (partial automation) and level three (conditional automation). However, AVs that are currently being trialed are equipped with full autonomy.

Table 1. Levels of vehicle automation [49].

\begin{tabular}{ccccccc}
\hline Source & $\mathbf{5}$ & \multicolumn{5}{c}{ Levels of Automation } \\
\cline { 2 - 6 } & $\mathbf{0}$ & $\mathbf{1}$ & $\mathbf{2}$ & $\mathbf{3}$ & $\mathbf{4}$ & $\mathbf{5}$ \\
\hline $\begin{array}{c}\text { Federal Highway } \\
\text { Research Institute } \\
\text { (BASt) }\end{array}$ & $\begin{array}{c}\text { Driver only } \\
\text { (Level 0) }\end{array}$ & $\begin{array}{c}\text { Assisted } \\
\text { (Level 1) }\end{array}$ & $\begin{array}{c}\text { Partly } \\
\text { automated } \\
\text { (Level 2) }\end{array}$ & $\begin{array}{c}\text { Highly } \\
\text { automated } \\
\text { (Level 3) }\end{array}$ & $\begin{array}{c}\text { Fully } \\
\text { automated } \\
\text { (Level 4) }\end{array}$ & - \\
\hline $\begin{array}{c}\text { National Highway } \\
\text { Traffic Safety }\end{array}$ & $\begin{array}{c}\text { No } \\
\text { automation } \\
\text { (Level 0) }\end{array}$ & $\begin{array}{c}\text { Function } \\
\text { specific } \\
\text { automation } \\
\text { (Level 1) }\end{array}$ & $\begin{array}{c}\text { Combined } \\
\text { function } \\
\text { autrationation } \\
\text { (Level 2) }\end{array}$ & $\begin{array}{c}\text { Limited } \\
\text { self-driving } \\
\text { automation } \\
\text { (Level 3) }\end{array}$ & $\begin{array}{c}\text { Full } \\
\text { self-driving } \\
\text { automation } \\
\text { (Level 4) }\end{array}$ & - \\
\hline $\begin{array}{c}\text { Society of } \\
\text { Automotive } \\
\text { Engineers (SAE) }\end{array}$ & $\begin{array}{c}\text { No } \\
\text { automation } \\
\text { (Level 0) }\end{array}$ & $\begin{array}{c}\text { Driver } \\
\text { assistance } \\
\text { (Level 1) }\end{array}$ & $\begin{array}{c}\text { Partial } \\
\text { automation } \\
\text { (Level 2) }\end{array}$ & $\begin{array}{c}\text { Conditional } \\
\text { automation } \\
\text { (Level 3) }\end{array}$ & $\begin{array}{c}\text { High } \\
\text { automation } \\
\text { (Level 4) }\end{array}$ & $\begin{array}{c}\text { automation } \\
\text { (Level 5) }\end{array}$ \\
\hline
\end{tabular}

The implementation horizon for AVs will move through each level of autonomy. Walker [50] predicts that General Motors (GM) and Ford will have level three and four AVs in use by 2021, although the traditional ownership model will not apply as early adoption will be through ride-sharing firms, as shown by GM's partial purchase of a stake in Lyft. Walker [50] notes that all major automobile firms have plans for mid-level AVs to be operationalized over the period of 2020-2030. In addition, vehicle producers (e.g., GM, Ford, Chrysler, Toyota, Daimler, Hyundai) are not only focusing on the production of $\mathrm{AVs}$, but they are partnering with software and robotics firms for product development, and with ride-sharing firms (e.g., Uber, Lyft) for implementation. The end product of mobility for consumers will look familiar, but the way that mobility is provided will be the result of a recombination of technologies and firms.

According to König and Grippenkoven [51], "[e]lectrification, connectivity and automation, as central trends in the upcoming generation of vehicles may not lead to a reduction of traffic but rather increase it. Future mobility is challenged to bundle up traffic demands to handle an increasing mobility demand caused by spatial sprawl, economic growth and flexible working hours. Looking at mobility from a psychological perspective another challenge arises-people strive for a more flexible form of mobility than mass public transport offers. They rather want schedules to adapt to their needs than to plan their mobility regarding to the fixed times of public transport" (p. 295). On that very point, the growing literature highlights that $\mathrm{AVs}$ ' impact is expected to be transformative as use grows with a range of social implications $[52,53]$. 
The widely raised implications of AVs in the literature include, but are not limited to, the following:

- The changing nature of mobility and AVs (e.g., demand responsive transport, vehicle ownership, pricing models, access for aging/children/disabled);

- The impact of AVs on the built environment (e.g., parking facilities, building and street design, signage);

- The need for a clear legal status of AVs (e.g., assignment of risk and responsibility, police practice);

- The improved security of AVs for efficient operation and public safety (e.g., driving performance, cyber security);

- The employment impacts of AVs on occupations and industries (e.g., loss of jobs in freight and public transport), and;

- The economic impact of $\mathrm{AVs}$ on three-tier government tax revenues (e.g., change in property and sales tax revenue).

\section{Discussion}

\subsection{What Could Be the Likely Impacts of Autonomous Vehicles on the Built Environment and Land Use?}

According to many planning scholars, such as Kane and Whitehead [54], "[e]xisting urban transport systems have fundamentally shaped our modern urban economies and societies, however, disruptive technologies, as fundamental as recent ICT disruptions, threaten major change" (p. 177). Moreover, it is believed that AV technology has the potential to transform travel behavior-also including pedestrians-and thus, the city [55]. Hence, in light of currently available insights, forecasts, and speculations from the literature [56], we further elaborated some of the likely changes to the built environment and land uses of our cities-in the case of a widespread AV utilization scenario. Here, we note that some of these predictions are only speculations at this early stage. Some expectations for positive consequences on our cities, societies, and the environment might actually end up generating undesired externalities-or vice versa. Thus, we consciously omitted to group them under the opportunities and constraints categories. We have also not factored in the cost differences of mobility with AVs when compared to normal cars.

The Built Environment and Land Use: There are two opposing perspectives on how AVs will disrupt the built environment and land use. As stated by Stead and Vaddadi [57], the optimistic view predicts that "[ $t$ ]he quality of the built environment will be improved (re-centralization or regeneration of inner areas, re-densification, land use changes to new green public areas, residential locations). [In this perspective,] AVs are seen as a way of promoting better quality of life in cities" (p. 126); while the pessimistic view suggests that "[ $t$ ]he built environment will be reshaped to accommodate the needs of $\mathrm{AVs}$ and their users in preference to the needs of other social groups. AVs increase suburbanization or sprawl due to the comfort of trips" (p. 126).

Redistribution of Road Spaces: The road network is a major land use of any city, occupying between $25 \%$ and $35 \%$ of total land. Lanes, in both number and space, may be reduced, as many AVs will be narrower, require less space between vehicles, and will be capable of sharing opposite-direction lanes as available [58]. Here, note that claims like these AV design characteristics are just projections based on the best utilization of current technology and infrastructure. In addition, with the help of platooning technology, AVs are expected to operate more efficiently in road networks (e.g., reduced inter-vehicle distance) and free up some spaces, enabling city planners to allocate the freed spaces (e.g., extra lanes) for social and community infrastructures. Likewise, some highways may need to be turned into boulevards that are a more appropriate use for civic life [59]. These changes will help create a better quality road network designed to move people, not just vehicles.

Optimization of Parking Spaces: On the one hand, AVs will likely find cheaper parking options and are thereby likely to decrease the need for parking in urban cores. The main reason for this reduced cost is that AVs can travel without passengers, and as a result, they do not necessarily need to be parked close to the activity locations of passengers. Historically, parking cost is generally higher in the CBD 
(or in activity centers) and declines away from these destinations. Hence, it is most likely that parking facilities will be outside the urban core in distributed locations, and they will include daytime or overnight charging facilities at the parking lots. Depending on the location and business models, some of these parking facilities might be in the form of the multi-level parking as in Figure 4. As a result, the requirements to provide obligatory parking spaces in these high-value property areas will need a re-estimation [60]. Reduction in parking lots will transform inner-city areas, as unoccupied parking space will be used for other activities—such as parks or affordable housing. This transformation will allow further realization of mixed-use precincts to trigger the trend of downtown living, creating inner-city areas that are more functional and livable. Meanwhile, some AV charging lots in and out of the city might also be used as mobile office locations. On the other hand, there also exists a pessimistic perspective. Highlighted in a review by Stead and Vaddadi [57], "parking policies will remain as they are (i.e., AVs will use on-road parking spaces). A growth in AV ownership and use leads to an increase in demand for parking spaces in the city. Large numbers of collection/drop-off points are created in the city which add to the amount of space allocated for vehicles" (p. 126).

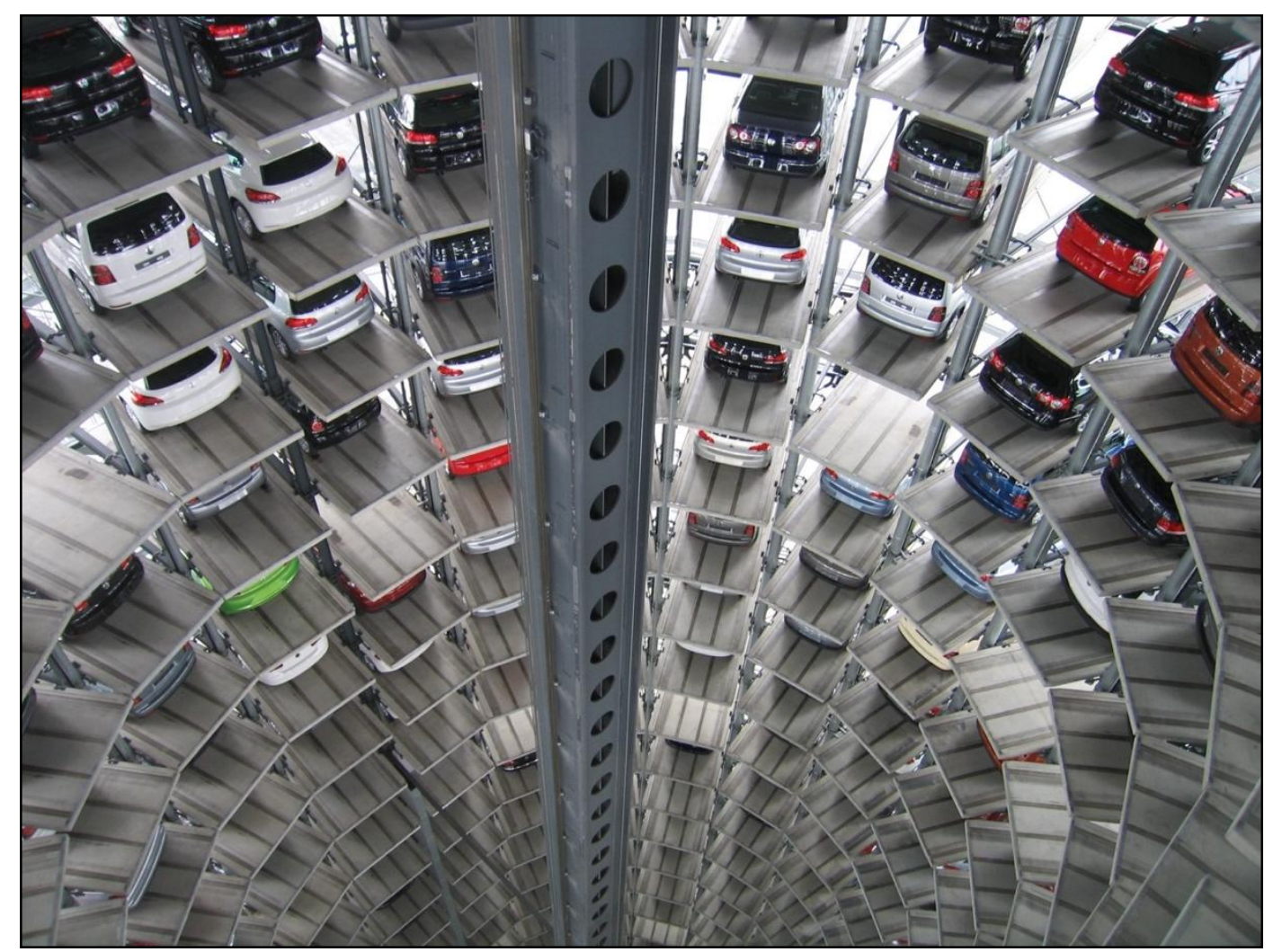

Figure 4. An exemplar parking space complex for autonomous vehicles, 2019. A copyright free photo by Pixabay from Pexels, https://www.pexels.com/photo/vehicles-parked-inside-elevated-parking-lot63294.

Redesigning Streets and Revisiting Building and Street Interfaces: With AVs, buildings in dense urban areas will have to become more adaptive to accommodate the flow as well as stoppage of vehicles. The buildings will need to be designed so that they can accommodate drop-offs and pick-ups to facilitate door-to-door services. The reason for this is that as AVs-particularly shared AVs-do not need to park as much as other cars, they will be doing more frequent drop-offs and pick-ups, and given the demand-driven nature of future transport rather than dedicated public transport stops, these vehicles will be willing to stop where possible. This increased stop and go activity will bring urban, transport, and building designers to redesign streetscapes. In other words, this changed behavior will support better formulation of streetscapes for an enhanced access for all users [61]. Furthermore, it will 
help shape the streetscape, in denser areas, to become more pedestrian friendly and truly complete streets-referring to balancing access of a street for all transport modes including pedestrians, bicyclists, motorists, and transit riders of all ages and abilities [62,63]. Better integration of land use and transport planning will help to come up with enhanced street design solutions [64-66].

Transforming Redundant Urban Spaces into New Land Uses: AVs will make some land uses obsolete-such as gas stations. AVs are, ideally, electric vehicles and charged at the charging stations located in parking spaces-that will most likely contain solar panels, which will serve dual purposes for the parked vehicles: provide shade and generate electricity [67]. There will be, thus, a rapidly decreasing need for gas stations as the number of electric AVs increase on the streets. These gas station locations may turn into other land uses to serve their neighborhoods-such as local corner shops or kiosks to collect goods purchased through online shopping.

Converting Redundant House Spaces in Suburbia: As a result of shared or pooled-shared AV services some people will give up private motor vehicle ownership [68]. This will have an impact on the parking and garage spaces in residential areas. Suburban home garages will be converted into private studios to be leased or rented for short-term lodging or turned into granny flats for accommodating a senior member of the family. Driveways will be turned into greened front yards, and cul-de-sacs may become a shared facility where children can play, and local inhabitants can walk and meet their neighbors-hence, contributing to the social capital of the local community.

General Decline of Settlement Densities and Increasing Urban Sprawl: AVs have the natural potential to create an induced urban sprawl-in other words, growth of low-density suburbs (Figure 5). AVs could trigger travel demand (necessary or not) particularly in high motor vehicle dependent societies [69]. They can result in more dispersed and fragmented land uses in the outskirts of cities [70]. This can occur when travel that is more effortless is seen as less of a burden and an invitation to travel more-unless legislators and planners act now. Optimization of accessibility of communities through better land use provision or allocation is required to discourage sprawl.

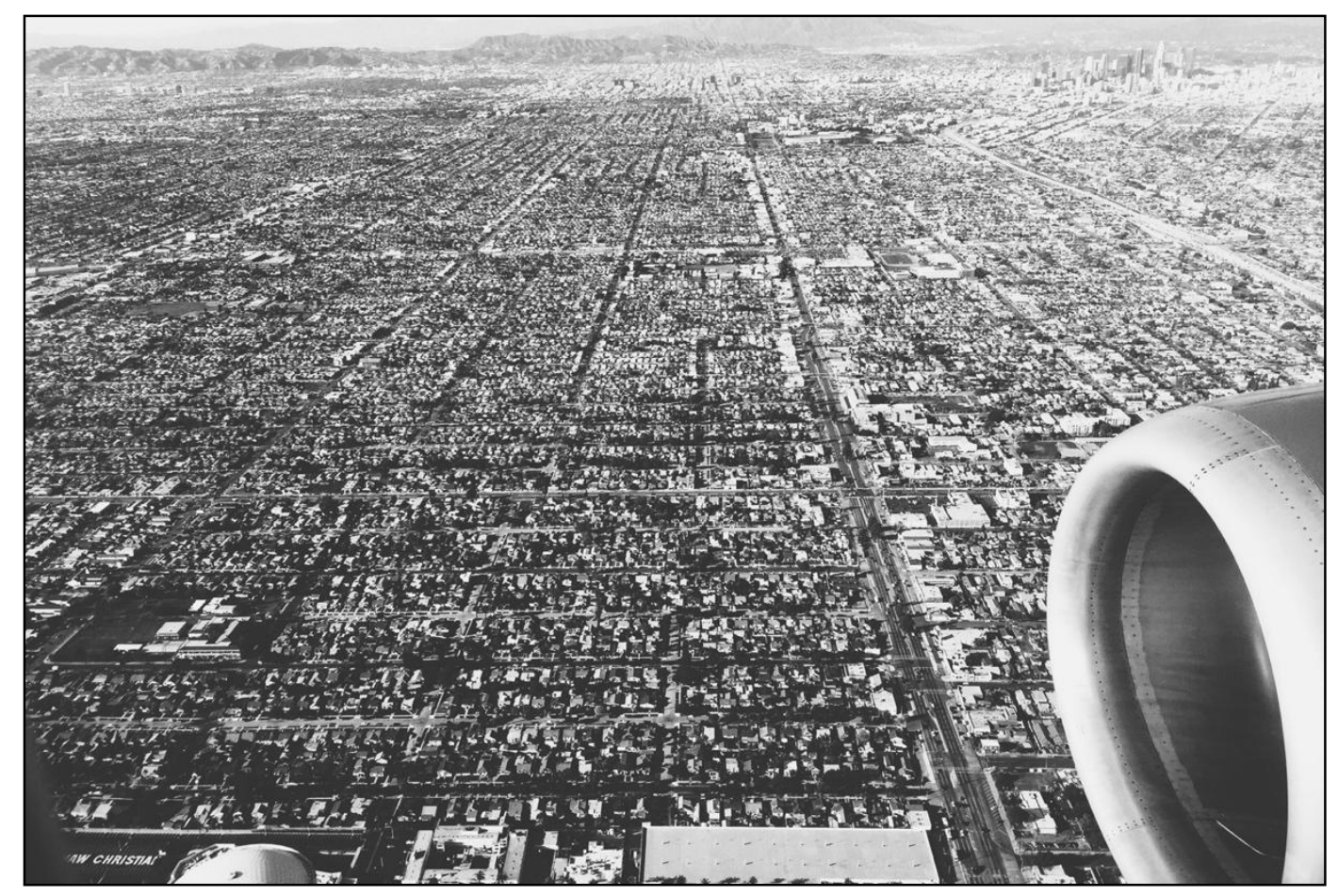

Figure 5. Sprawling development of Los Angeles, 2019. A copyright free photo by StockSnap from Pixabay, https://pixabay.com/photos/la-los-angeles-aerial-airplane-926515. 
The Unequal Property Value Distribution, Development Controls and Supply: While the popular real estate slogan of location-location-location will still keep its relevance, AVs will disproportionately affect property values across a city [71]. Particularly, even though the travel time will increase, it may generate a reduced value of travel time-meaning that as there is no driving task or stress, travel time can be used for other activities. This will influence some people to relocate to suburban areas to enjoy a large lot with gardens. In contrast, urban areas might also experience density gain through land use optimization as discussed previously. As a result, urban growth management would be a key challenge to ensure that there is an adequate supply of land to meet the preferences of people without compromising the sustainability of urban areas.

The Environmental Impact of the Use of AVs: The intrinsic technical attributes of AVs appear to be largely favorable in the literature [72]. Moving away from fossil fuel-based energy in electric AVs (given energy is generated from solar, wind or so on) is a positive step to lower the environmental undesired externalities. This is particularly true for AVs' potential for increasing ride-sharing and thus shift personal transportation from individually owned vehicles toward shared-use mobility services [73]. However, increased efficiency and effectiveness of the transport system, as a result of advanced autonomous driving technology, may lead to increased travel speeds and hence increasing greenhouse gas (GHG) emissions [74]. In other words, as stated by Miller and Heard [75], "[i]t is plausible that AVs could become more efficient and GHG emissions could decrease on a functional unit basis (i.e., per-passenger-mile), while overall transport-related GHG emissions increase as vehicle miles traveled (VMT) increase" (p. 6119). Increased mobility and travel convenience could lead to urban sprawl and a rapid expansion of the urban footprint - that is a contributor to the changing climate [76]. Besides the environmental harm of greenfield developments-converting green or agricultural land into urban land uses (Figure 6) - it induces additional GHG emissions due to long travel distance.

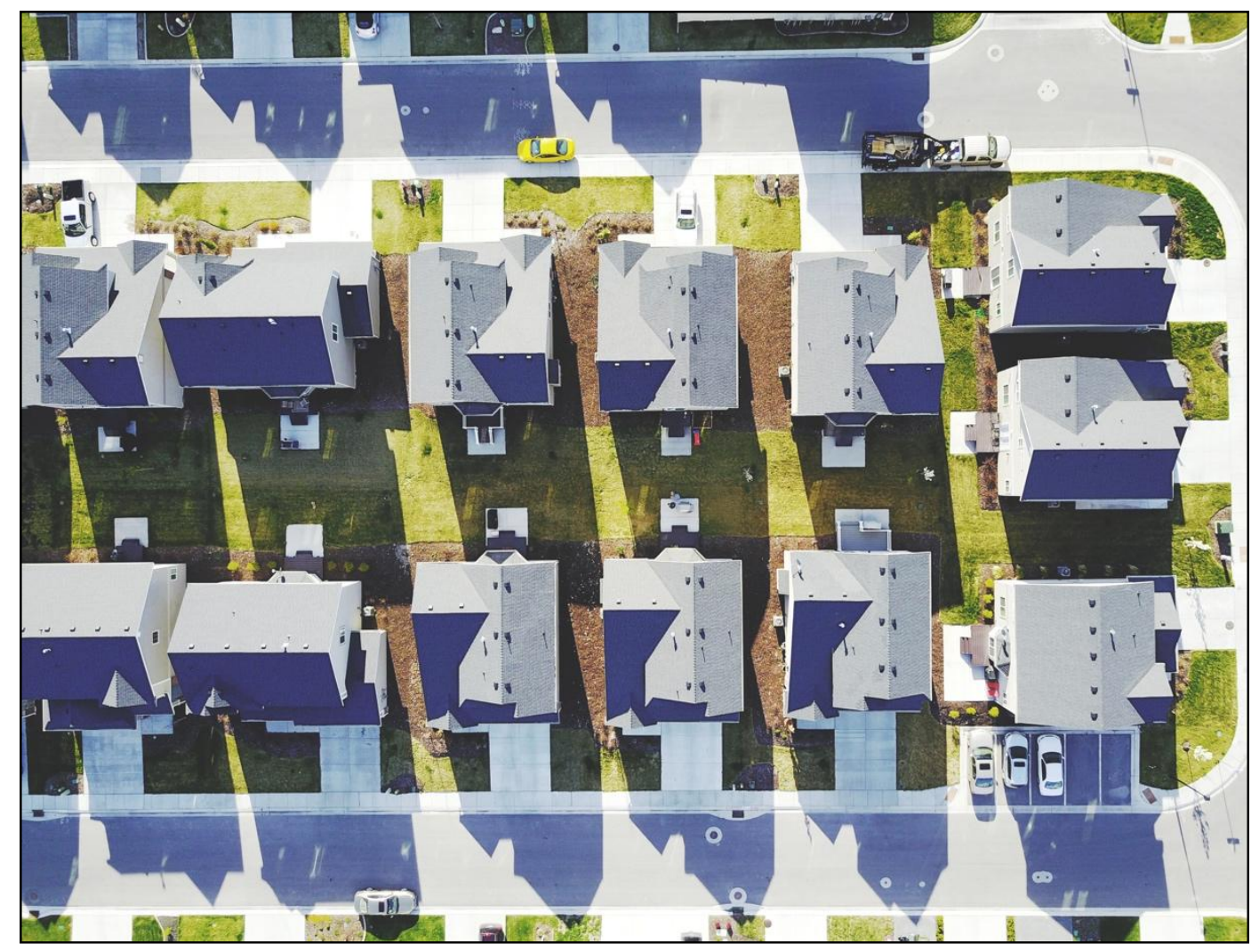

Figure 6. Greenfield development, 2019. A copyright free photo by Public Co from Pixabay, https: //pixabay.com/photos/suburbs-homes-neighbors-2211335. 
In support of the abovementioned aspects, Table 2 highlights some of the contrasting (i.e., optimistic and pessimistic) perspectives on the likely impacts of AVs on our cities and societies put together in the review study of Papa and Ferreira [77]. However, the gray tones or the mid views between the optimistic and pessimistic perspectives should be considered.

Table 2. Diverse views on the likely impacts of AVs. Derived from [77].

\begin{tabular}{|c|c|c|}
\hline Impact Themes & Optimistic View & Pessimistic View \\
\hline $\begin{array}{l}\text { The built } \\
\text { environment } \\
\text { and land use }\end{array}$ & $\begin{array}{l}\text { The built environment will be seen as a place } \\
\text { to live and experience quality of life. Mobility } \\
\text { will be seen as something that should } \\
\text { promote quality of life. These guiding } \\
\text { principles will be unchanged in the face of } \\
\text { pressures coming from enthusiasts of AVs. }\end{array}$ & $\begin{array}{l}\text { The built environment will be reshaped to } \\
\text { accommodate the complex and ever-increasing } \\
\text { needs of AVs and their users against the needs } \\
\text { of other social groups. }\end{array}$ \\
\hline $\begin{array}{l}\text { Environmental } \\
\text { sustainability }\end{array}$ & $\begin{array}{l}\text { The development and implementation of } \mathrm{AVs} \\
\text { will be regulated considering strong } \\
\text { environmental concerns. }\end{array}$ & $\begin{array}{l}\text { AVs will be developed and implemented with } \\
\text { little concern for sustainability. Marketing } \\
\text { campaigns will distract people from } \\
\text { environmental issues and focus their attention } \\
\text { on individual benefits associated with } \\
\text { automated transport. }\end{array}$ \\
\hline Parking & $\begin{array}{l}\text { Parking policies will facilitate the conversion } \\
\text { of no longer needed parking places into new } \\
\text { recreational, green, and building areas, or into } \\
\text { transport infrastructures for active modes } \\
\text { of transport. }\end{array}$ & $\begin{array}{l}\text { Parking policies will remain as they are, that is, } \\
\text { when not in use AVs will use on-road parking } \\
\text { spaces and existing parking areas that consume } \\
\text { highly desirable land that could be used for } \\
\text { more sustainable or social purposes. }\end{array}$ \\
\hline Vehicle sharing & $\begin{array}{l}\text { AVs will not be primarily advertised and sold } \\
\text { as private property for those who can afford it. } \\
\text { Instead, the notion of automated car sharing } \\
\text { will be promoted from the start. }\end{array}$ & $\begin{array}{l}\text { AVs will be promoted by developers as private } \\
\text { property for the elites who can afford them. } \\
\text { It will be seen first as a luxury item and this will } \\
\text { create negative path-dependency during } \\
\text { several decades. }\end{array}$ \\
\hline Public transport & $\begin{array}{l}\text { Public transport services will be protected } \\
\text { and sponsored by National and Local policies } \\
\text { so that the (probable) high appeal of AVs does } \\
\text { not exclude these public services from the } \\
\text { transport system. }\end{array}$ & $\begin{array}{l}\text { National, regional, and local policies focus on } \\
\text { AVs too much and fail to support public } \\
\text { transport providers against the competition } \\
\text { represented by AVs. As a result, public } \\
\text { transport becomes increasingly marginalized } \\
\text { and ceases to operate in a growing number } \\
\text { of places. }\end{array}$ \\
\hline Social exclusion & $\begin{array}{l}\text { The use of AVs will be open to a vast share of } \\
\text { the population due to policies aimed at } \\
\text { fighting social exclusion potentially induced } \\
\text { by transport automation. Measures will be } \\
\text { considered to avoid the creation of } \\
\text { circumstances where AVs become } \\
\text { compulsory replacements for conventional } \\
\text { homes as people will not be able to pay for a } \\
\text { car and a house mortgage. }\end{array}$ & $\begin{array}{l}\text { The use of AVs will be exclusive to those with } \\
\text { the ability and willingness to pay for what will } \\
\text { be considered a privileged mode of transport. } \\
\text { Conversely, vulnerable societal groups will be } \\
\text { encouraged to use AVs as a place to live and } \\
\text { travel under constant scrutiny. }\end{array}$ \\
\hline $\begin{array}{c}\text { Transport } \\
\text { network design }\end{array}$ & $\begin{array}{l}\text { Transport networks will be designed in ways } \\
\text { that will be safe for all. In urban settings there } \\
\text { will be great care to provide for the needs of } \\
\text { sustainable transport modes. }\end{array}$ & $\begin{array}{l}\text { Transport networks will experience massive } \\
\text { restructuring to accommodate the unique needs } \\
\text { of AVs. Other transport modes will not see a } \\
\text { comparable level of protection and investment. }\end{array}$ \\
\hline $\begin{array}{l}\text { Inter-modal } \\
\text { traffic } \\
\text { regulations }\end{array}$ & $\begin{array}{l}\text { AVs will be programmed to respect } \\
\text { unconditionally all forms of human life. } \\
\text { Instead of focusing on which lives should be } \\
\text { saved in the case of accidents involving AVs, } \\
\text { the focus will be on changing traffic } \\
\text { regulations to make accidents less likely } \\
\text { (e.g., through lower speeds). Pedestrians and } \\
\text { other vulnerable road users will be protected } \\
\text { by the spirit of the law. }\end{array}$ & $\begin{array}{l}\text { The debate on inter-modal traffic regulations } \\
\text { will focus on the value of human lives when } \\
\text { considering characteristics of individual road } \\
\text { users. First these characteristics will be age and } \\
\text { probability of survival, but later on will be } \\
\text { characteristics such as income, quality of } \\
\text { insurance coverage, citizenship status, } \\
\text { and criminal record. The rights of users of AVs } \\
\text { will be protected by the spirit of the law. }\end{array}$ \\
\hline
\end{tabular}


Table 2. Cont.

\begin{tabular}{cll}
\hline Impact Themes & \multicolumn{1}{c}{ Optimistic View } & \multicolumn{1}{c}{ Pessimistic View } \\
\hline $\begin{array}{c}\text { Automated } \\
\text { cooperation }\end{array}$ & $\begin{array}{l}\text { The operating systems of AVs will be } \\
\text { programmed using as guidelines cooperative, } \\
\text { altruistic, and ethical principles. }\end{array}$ & $\begin{array}{l}\text { The operating systems of AVs will be } \\
\text { programmed using as guidelines competitive, } \\
\text { aggressive, and defensive principles. }\end{array}$ \\
\hline $\begin{array}{c}\text { Network } \\
\text { information } \\
\text { systems }\end{array}$ & $\begin{array}{l}\text { Investments will be made so that all AVs can } \\
\text { use network data to make more sustainable } \\
\text { and efficient decisions regarding route choice } \\
\text { and parking at a fleet level. }\end{array}$ & $\begin{array}{l}\text { There will be little to no developments } \\
\text { dedicated to co-creating public information } \\
\text { systems that will facilitate overall efficiency and } \\
\text { sustainability at fleet level and as a result } \\
\text { vehicles will be equipped (or not) with } \\
\text { information gathering devices based on the } \\
\text { willingness and ability to pay of their users. }\end{array}$ \\
\hline $\begin{array}{l}\text { Sensitive data } \\
\text { management }\end{array}$ & $\begin{array}{l}\text { Personal data and all forms of information } \\
\text { that might be used against individuals or } \\
\text { organizations will be carefully managed or } \\
\text { not recorded, and always with the purpose of } \\
\text { providing for the needs of vulnerable } \\
\text { individuals or in the name of the public } \\
\text { interest. }\end{array}$ & $\begin{array}{l}\text { Growing quantities of data will be stored and } \\
\text { used for commercial or societal control } \\
\text { purposes. AVs will be understood as data } \\
\text { extraction devices, making it compulsory for } \\
\text { their users to reveal increasingly larger and } \\
\text { more sensitive private information. }\end{array}$ \\
\hline
\end{tabular}

\subsection{How Can Planners Mitigate the Built Environment and Land Use Disruption of Autonomous Vehicles?}

$\mathrm{AVs}$, the convergence of automation, electrification, and ride-sharing technologies, have the potential to substantially alter land use patterns of cities-as was evident during the automobile induced changes in land use patterns in the early 20th century. AVs are mobility technologies whose impact will be shaped by adoption practices, the planning profession and communities can shape implementation to lead to improved urban life, but $\mathrm{AVs}$ can also exacerbate many current problems [78]. For every dream held by a planner for AVs, there is also a nightmare. The desire for shared vehicles and reduced travel can be countered with the growth in zero passenger trips or the shift to AVs could cannibalize efficient public transport like subways and replace journeys with road transport. Nevertheless, how can urban planners mitigate the disruption of AVs on our cities and societies?

On that very point, Kane and Whitehead [54] warn us: "Urban transport disruptions present a unique challenge and opportunity for planners and policymakers to influence and shape outcomes for society. The role of urban planners and policymakers in future transport systems will become increasingly important as mobility disruptions start to radically transform transport systems. Without sensible and informed public policy, future urban mobility disruptions have the potential to lead to a series of non-optimal outcomes, of which some may result in transport systems functioning worse than they do at present" (p. 177).

Today, AVs are less of a discussion about 'if it will be a reality' but the discussion is more focused on 'when it will be available'. Despite the technology being realized at a faster pace, city managers unfortunately remain unprepared in addressing the long-term disruption by the technology, and thereby the ability to exploit the short-term benefits. Planners need to focus on changing their planning models to incorporate the expected disruptive impact of AV technology, along with finding ways to intelligently re-use current land uses and buildings. Scott [79] suggests the following two practical guidelines that need to be integrated into current investigations and processes at the national, state, and local levels:

- Advocating for a set of guiding principles for planners to follow, and;

- Lobbying for funding to undertake specific further studies to develop aforementioned guiding principles and mitigation strategies. 


\section{Conclusions}

In the age of smart urbanism, planning faces a perfect storm of disruptive technologies that includes AVs [80-83]. As Zakharenko [84] stated, self-driving cars will change cities. As discussed above, these changes are solely associated with the widespread adoption of AVs. It is also to be noted that some of these effects can partially be observed without AVs when a major shift in travel behavior occurs from personal mobility to shared mobility. For example, efficiency in road spaces is likely to be observed when the majority of people shift from the car to public transport. However, these efficiency gains are not due to the development in vehicle technology (e.g., platooning capability). This necessitates urban managers to prepare long-term strategies to manage the potential disruptions in cities. Despite that in recent years some planning scholars have turned their attention to this $[18,85,86]$, there is very little consensus on what the disruptions will be and how they will be addressed. In the absence of clear directions, this viewpoint highlights how planners must deal with all changes together in a holistic response to technology. It advocates that planners should not be passive, but proactive agents who can harness the benefits and minimize the disadvantages of a new mobility landscape.

The challenges of new technologies have long been confronted and harnessed by urban planners [87]. However, what is essential to the process, first of all, is a need to be aware of technological change and engage with communities over the form and nature of change. What actually complicates this process is the limited social science scholarship on the impact of AVs on our cities and societies. The engineering literature is well developed, but the corresponding social science insights are only now emerging. However, as stated by Miller and Heard [75], further "research is needed to model the complex and dynamic nature of AVs, integrating technical, behavioral, and transportation design elements" (p. 6120).

An additional challenge for planners is that AVs are not an isolated technological change to be nested into existing communities, but are one of several major disruptions that need to be managed simultaneously. Planning faces a perfect storm of disruptive technologies that includes the impact of the internet (and digital revolution) on the nature of retailing, organization of work, and social interaction [88], plus growing affordability of locally produced solar and wind power, to be followed by AVs and innovations such as e-scooters. Planners must deal with all changes together in a holistic response to technology, perhaps also considering the wider environmental and economic effects of AVs that are not elaborated in this viewpoint.

Perhaps one of the first actions to be taken by planners is to engage in developing 'what-if' scenarios to define plausible ranges of outcomes to envision potential policies or designs that will reduce undesired consequences of AVs in our cities [89-91]. The literature focusing on the social impacts of AVs offers a typology for such scenarios. For instance, according to Stead and Vaddadi [57], these scenarios can be classified under the following four main types (p. 127):

- Business as Usual: Reference scenarios that assume the continuation of one or more current trends (i.e., in mobility, urban development, and/or demographics), without the introduction of AVs;

- Technology and Non-Shared: Scenarios that assume the introduction of AVs, which are either solely or predominantly individually owned and used;

- Technology and Shared: Scenarios that assume the introduction of AVs, which are solely or predominantly shared, and;

- Technology and Shared and Infrastructure or Policy: Scenarios that assume the introduction of AVs, which are solely or predominantly shared. Plus, supportive policies and/or infrastructures are introduced to actively promote the uptake and use of AVs.

In response to the AV challenges raised in this viewpoint for our cities and societies, the other important action items to be considered for the planning discipline and practice include, but are not exclusively limited to, the following:

- Making an inventory of the short- and long-term effects of AVs and prioritize policy interventions accordingly; 
- Ex-ante evaluation or modelling of both the short- and long-term effects to identify the overall benefit/loss from AVs. For example, congestion relief could be a short-term effect of AVs. Such initial benefit may disappear in the long-run when AVs induce changes in land use patterns which consequently results in higher vehicle kilometers traveled (VKT), and;

- Planning for the future based on the modelling outcomes. For example, saved road spaces can be released for alternative use or can be banked to facilitate movement in the future. Similarly, urban growth modelling with AVs allows planners to foresee future development trends, which will inform to prepare for infrastructure needed to facilitate growth (sprawl) or to formulate alternative growth management strategies.

Lastly, we conclude this viewpoint by quoting Stead and Vaddadi [57] that lucidly stress the critical role of planning, regulating, and policymaking for mitigating the disruptive impacts of autonomous driving technology: "Ultimately, the future role of AVs in influencing urban form and structure is not so much dependent on the technology and level of automation of vehicles but rather on the regulation of this technology and the governance of cities and regions" (p. 132).

Author Contributions: T.Y. designed the study. T.Y. and M.W. prepared the first draft of the manuscript. M.K. contributed to the write up and improved the rigor and flow of the manuscript. T.Y., M.W. and M.K. contributed to the revision of the manuscript. All authors read and approved the final version of the manuscript.

Funding: This paper was presented as a keynote speech of SOItmC 2019, and the publishing fee was supported by SOItmC.

Acknowledgments: This research did not receive any specific grant from funding agencies in the public, commercial or not-for-profit sectors. The authors thank the Editor-in-Chief Yun and anonymous referees for their invaluable comments on an earlier version of the manuscript.

Conflicts of Interest: The authors declare no conflict of interest.

\section{References}

1. Luque-Ayala, A.; Marvin, S. Developing a critical understanding of smart urbanism? Urban Stud. 2015, 52, 2105-2116. [CrossRef]

2. Trindade, E.P.; Hinnig, M.P.; Moreira da Costa, E.; Marques, J.; Bastos, R.; Yigitcanlar, T. Sustainable development of smart cities: A systematic review of the literature. J. Open Innov. Technol. Mark. Complex. 2017, 3, 11. [CrossRef]

3. Han, H.; Hawken, S. Introduction: Innovation and identity in next-generation smart cities. City Cult. Soc. 2018, 12, 1-4. [CrossRef]

4. Yigitcanlar, T.; Kamruzzaman, M.; Foth, M.; Sabatini-Marques, J.; Costa, E.; Ioppolo, G. Can cities become smart without being sustainable? A systematic review of the literature. Sustain. Cities Soc. 2019, 45, 348-365. [CrossRef]

5. Townsend, A.M. Smart Cities: Big Data, Civic Hackers, and the Quest for a New Utopia; WW Norton \& Company: New York, NY, USA, 2013.

6. Yigitcanlar, T. Technology and the City: Systems, Applications and Implications; Routledge: New York, NY, USA, 2016.

7. Kellerman, A. Automated and Autonomous Spatial Mobilities; Edward Elgar: Cheltenham, UK, 2018.

8. Yigitcanlar, T. Smart cities: An effective urban development and management model? Aust. Plan. 2015, 52, 27-34. [CrossRef]

9. Docherty, I.; Marsden, G.; Anable, J. The governance of smart mobility. Transp. Res. Part A 2018, 115, 114-125. [CrossRef]

10. Pentland, B.; Bailey, D.; Cefkin, M.; Cotten, S.; Crowston, K.; Erickson, I.; Kassens Noor, E.; Kennedy, J.P.; King, J.L.; Madill, H.A.; et al. Connected and Autonomous Vehicles in Society: An Agenda for Social and Policy Research; Center for Business and Social Analytics: East Lansing, MI, USA, 2018.

11. Yigitcanlar, T.; Kamruzzaman, M. Smart cities and mobility: Does the smartness of Australian cities lead to sustainable commuting patterns? J. Urban Technol. 2019, 26, 21-46. [CrossRef] 
12. Caragliu, A.; Del Bo, C.; Nijkamp, P. Smart cities in Europe. J. Urban Technol. 2011, 18, 65-82. [CrossRef]

13. Albino, V.; Berardi, U.; Dangelico, R.M. Smart cities: Definitions, dimensions, performance, and initiatives. J. Urban Technol. 2015, 22, 3-21. [CrossRef]

14. Ahvenniemi, H.; Huovila, A.; Pinto-Seppä, I.; Airaksinen, M. What are the differences between sustainable and smart cities? Cities 2017, 60, 234-245. [CrossRef]

15. Benevolo, C.; Dameri, R.P.; D'Auria, B. Smart mobility in smart city. In Empowering Organizations; Springer: Cham, Switzerland, 2016; pp. 13-28.

16. Olaverri-Monreal, C. Autonomous vehicles and smart mobility related technologies. Infocommun. J. 2016, 8, 17-24.

17. Lyons, G. Getting smart about urban mobility: Aligning the paradigms of smart and sustainable. Transp. Res. Part A Policy Pract. 2018, 115, 4-14. [CrossRef]

18. Faisal, A.; Yigitcanlar, T.; Kamruzzaman, M.; Currie, G. Understanding autonomous vehicles: A systematic literature re- view on capability, impact, planning and policy. J. Transp. Land Use 2019, 12, 45-72. [CrossRef]

19. Chun, B.T.; Lee, S.H. Review on ITS in smart city. Adv. Sci. Technol. Lett. 2015, 98, 52-54.

20. Kim, J.; Moon, Y.J.; Suh, I.S. Smart mobility strategy in Korea on sustainability, safety and efficiency toward 2025. IEEE Intell. Transp. Syst. Mag. 2015, 7, 58-67. [CrossRef]

21. Garau, C.; Masala, F.; Pinna, F. Cagliari and smart urban mobility: Analysis and comparison. Cities 2016, 56, 35-46. [CrossRef]

22. Fagnant, D.J.; Kockelman, K. Preparing a nation for autonomous vehicles. Transp. Res. Part A 2015, 77, $167-181$.

23. Duarte, F.; Ratti, C. The impact of autonomous vehicles on cities: A review. J. Urban Technol. 2018, $25,3-18$. [CrossRef]

24. Hand, A.Z. Redefining urban mobility. Glob. Real Estate 2017, 3, 49-52.

25. Legacy, C.; Ashmore, D.; Scheurer, J.; Stone, J.; Curtis, C. Planning the driverless city. Transp. Rev. 2019, 39, 84-102. [CrossRef]

26. Pendleton, S.D.; Andersen, H.; Du, X.; Shen, X.; Meghjani, M.; Eng, Y.H.; Ang, M.H. Perception, planning, control, and coordination for autonomous vehicles. Machines 2017, 5, 6. [CrossRef]

27. Barone, R.E.; Giuffrè, T.; Siniscalchi, S.M.; Morgano, M.A.; Tesoriere, G. Architecture for parking management in smart cities. IET Intell. Transp. Syst. 2013, 8, 445-452. [CrossRef]

28. Salerno, V.; Rabbeni, G. An extreme learning machine approach to effective energy disaggregation. Electronics 2018, 7, 235. [CrossRef]

29. Bansal, P.; Kockelman, K.M.; Singh, A. Assessing public opinions of and interest in new vehicle technologies: An Austin perspective. Transp. Res. Part C Emerg. Technol. 2016, 67, 1-4. [CrossRef]

30. Bonnefon, J.F.; Shariff, A.; Rahwan, I. The social dilemma of autonomous vehicles. Science 2016, 352, $1573-1576$. [CrossRef] [PubMed]

31. Brodsky, J.S. Autonomous vehicle regulation: How an uncertain legal landscape may hit the brakes on self-driving cars. Berkeley Technol. Law J. 2016, 31, 851-877.

32. Wilson, M. Driverless Cars are Already here but the Roads Aren't Ready for Them. Available online: https: //theconversation.com/driverless-cars-are-already-here-but-the-roads-arent-ready-for-them-93456 (accessed on 4 April 2018).

33. Litman, T. Autonomous Vehicle Implementation Predictions; Victoria Transport Policy Institute: Victoria, BC, Canada, 2017.

34. Bloomberg. Is Your City Getting Ready for AVs? Available online: http://avsincities.bloomberg.org/globalatlas (accessed on 14 August 2018).

35. Ticoll, D. Driving Changes; University of Toronto: Toronto, ON, Canada, 2015.

36. Yigitcanlar, T.; Inkinen, T. Geographies of Disruption: Place Making for Innovation in the Age of Knowledge Economy; Springer: Cham, Switzerland, 2019.

37. Truong, L.T.; De Gruyter, C.; Currie, G.; Delbosc, A. Estimating the trip generation impacts of autonomous vehicles on car travel in Victoria. Transportation 2017, 44, 1279-1292. [CrossRef]

38. Kim, K.H.; Yook, D.H.; Ko, Y.S.; Kim, D.H. An Analysis of Expected Effects of the Autonomous Vehicles on Transport and Land Use in Korea; New York University: New York, NY, USA, 2015. 
39. Kamruzzaman, M.; Hine, J.; Yigitcanlar, T. Investigating the link between carbon dioxide emissions and transport-related social exclusion in rural Northern Ireland. Int. J. Environ. Sci. Technol. 2015, 12, 3463-3478. [CrossRef]

40. Pettigrew, S.; Talati, Z.; Norman, R. The health benefits of autonomous vehicles: Public awareness and receptivity in Australia. Aust. N. Z. J. Public Health 2018, 42, 480-483. [CrossRef]

41. Yigitcanlar, T.; Mohamed, A.; Kamruzzaman, M.; Piracha, A. Understanding transport-related social exclusion: A multidimensional approach. Urban Policy Res. 2019, 37, 97-110. [CrossRef]

42. Sun, Y.; Olaru, D.; Smith, B.; Greaves, S.; Collins, A. Road to autonomous vehicles in Australia: An exploratory literature review. Road Transp. Res. 2017, 26, 100-112.

43. Nikitas, A.; Kougias, I.; Alyavina, E.; Njoya Tchouamou, E. How can autonomous and connected vehicles, electromobility, BRT, hyperloop, shared use mobility and mobility-as-a-service shape transport futures for the context of smart cities? Urban Sci. 2017, 1, 36. [CrossRef]

44. Christie, D.; Koymans, A.; Chanard, T.; Lasgouttes, J.M.; Kaufmann, V. Pioneering driverless electric vehicles in Europe. Transp. Res. Procedia 2016, 13, 30-39. [CrossRef]

45. Tirachini, A.; Gomez-Lobo, A. Does ride-hailing increase or decrease vehicle kilometers traveled (VKT)? A simulation approach for Santiago de Chile. Int. J. Sustain. Transp. 2019, 23, 1-8. [CrossRef]

46. Gasser, T.M.; Westhoff, D. BASt-study: Definitions of automation and legal issues in Germany. In Proceedings of the 2012 Road Vehicle Automation Workshop, Irvine, CA, USA, 25 July 2012.

47. National Highway Traffic Safety Administration. Early Estimate of Motor Vehicle Traffic Fatalities in 2012; National Highway Traffic Safety Administration (NHTSA): Washington, DC, USA, 2013.

48. Society of Automotive Engineers. Taxonomy and Definitions for Terms Related to Driving Automation Systems for on-Road Motor Vehicles. Available online: https://www.sae.org/standards/content/j3016_201806 (accessed on 14 August 2018).

49. Kyriakidis, M.; Happee, R.; de Winter, J.C. Public opinion on automated driving: Results of an international questionnaire among 5000 respondents. Transp. Res. Part F Traffic Psychol. Behav. 2015, 32, 127-140. [CrossRef]

50. Walker, J. The Self-Driving Car Timeline. Available online: https:/emerj.com/ai-adoption-timelines/selfdriving-car-timeline-themselves-top-11-automakers (accessed on 14 August 2018).

51. König, A.; Grippenkoven, J. From public mobility on demand to autonomous public mobility on demand: Learning from dial-a-ride services in Germany. Logist. Supply Chain Manag. 2017, 13, 295-305.

52. Fuller, B. Cautious optimism about driverless cars and land use in American metropolitan areas. Cityscape 2017, 18, 181-184.

53. Fraedrich, E.; Heinrichs, D.; Bahamonde-Birke, F.J.; Cyganski, R. Autonomous driving, the built environment and policy implications. Transp. Res. Part A Policy Pract. 2019, 122, 162-172. [CrossRef]

54. Kane, M.; Whitehead, J. How to ride transport disruption-A sustainable framework for future urban mobility. Aust. Plan. 2017, 54, 177-185. [CrossRef]

55. Millard-Ball, A. Pedestrians, autonomous vehicles, and cities. J. Plan. Educ. Res. 2018, 38, 6-12. [CrossRef]

56. Guerra, E. Planning for cars that drive themselves. J. Plan. Educ. Res. 2016, 36, 210-224. [CrossRef]

57. Stead, D.; Vaddadi, B. Automated vehicles and how they may affect urban form: A review of recent scenario studies. Cities 2019, 92, 125-133. [CrossRef]

58. Schlossberg, M.; Millard-Ball, A.; Shay, E.; Riggs, W.B. Rethinking the Street in an era of Driverless Cars; University of Oregon: Portland, OR, USA, 2018.

59. Yigitcanlar, T.; Currie, G.; Kamruzzaman, M. Driverless Vehicles Could Bring out the Best—Or worst—In Our Cities by Transforming Land Use. Available online: https://theconversation.com/driverless-vehicles-couldbring-out-the-best-or-worst-in-our-cities-by-transforming-land-use-84127 (accessed on 4 October 2017).

60. Heinrichs, D. Autonomous driving and urban land use. In Autonomous Driving; Springer: Berlin, Germany, 2016; pp. 213-231.

61. Hajrasouliha, A.; Anderson, E.; Barker, M.; Harrison, K.; Hernandez, E.; Howland, S.; Pasanen, M. Designing for a driverless future in downtown San Luis Obispo. Focus 2019, 15, 20.

62. Burden, D.; Litman, T. America needs complete streets. ITE J. 2011, 81, 36-43.

63. Foster, R. Integrating Autonomous Vehicles into Complete Streets. Available online: https://medium. com/@robert.m.fostr/integrating-autonomous-vehicles-into-complete-streets-e7f930c150b5 (accessed on 14 August 2018). 
64. Dur, F.; Yigitcanlar, T.; Bunker, J. A spatial-indexing model for measuring neighbourhood-level land-use and transport integration. Environ. Plan. B 2014, 41, 792-812. [CrossRef]

65. Yigitcanlar, T.; Kamruzzaman, M. Investigating the interplay between transport, land use and the environment: A review of the literature. Int. J. Environ. Sci. Technol. 2014, 11, 2121-2132. [CrossRef]

66. Dur, F.; Yigitcanlar, T. Assessing land-use and transport integration via a spatial composite indexing model. Int. J. Environ. Sci. Technol. 2015, 12, 803-816. [CrossRef]

67. Nunes, P.; Figueiredo, R.; Brito, M.C. The use of parking lots to solar-charge electric vehicles. Renew. Sustain. Energy Rev. 2016, 66, 679-693. [CrossRef]

68. Krueger, R.; Rashidi, T.H.; Rose, J.M. Preferences for shared autonomous vehicles. Transp. Res. Part C 2016, 69, 343-355. [CrossRef]

69. Yigitcanlar, T.; Fabian, L.; Coiacetto, E. Challenges to urban transport sustainability and smart transport in a tourist city: The Gold Coast. Open Transp. J. 2008, 2, 29-46. [CrossRef]

70. Anderson, J.M.; Nidhi, K.; Stanley, K.D.; Sorense, P.; Samaras, C.; Oluwatola, O.A. Autonomous Vehicle Technology; RAND Corporation: Santa Monica, CA, USA, 2014.

71. Henderson, J.; Spencer, J. Autonomous vehicles and commercial real estate. Cornell Real Estate Rev. 2016, 14,14 .

72. Fagnant, D.J.; Kockelman, K. The travel and environmental implications of shared autonomous vehicles, using agent-based model scenarios. Transp. Res. Part C 2014, 40,1-13. [CrossRef]

73. Zhang, W.; Guhathakurta, S.; Fang, J.; Zhang, G. Exploring the impact of shared autonomous vehicles on urban parking demand: An agent-based simulation approach. Sustain. Cities Soc. 2015, 19, 34-45. [CrossRef]

74. Greenblatt, J.B.; Shaheen, S. Automated vehicles, on-demand mobility, and environmental impacts. Curr. Sustain. Renew. Energy Rep. 2015, 2, 74-81. [CrossRef]

75. Miller, S.A.; Heard, B.R. The environmental impact of autonomous vehicles depends on adoption patterns. Environ. Sci. Technol. 2016, 50, 6119-6121. [CrossRef]

76. Goonetilleke, A.; Yigitcanlar, T.; Ayoko, G.A.; Egodawatta, P. Sustainable Urban Water Environment: Climate, Pollution and Adaptation; Edward Elgar: Cheltenham, UK, 2014.

77. Papa, E.; Ferreira, A. Sustainable accessibility and the implementation of automated vehicles: Identifying critical decisions. Urban Sci. 2018, 2, 5. [CrossRef]

78. Penmetsa, P.; Adanu, E.K.; Wood, D.; Wang, T.; Jones, S.L. Perceptions and expectations of autonomous vehicles: A snapshot of vulnerable road user opinion. Technol. Forecast. Soc. Chang. 2019, 143, 9-132. [CrossRef]

79. Scott, M. Autonomous vehicles: How will they impact on cities? What role should planners play? Plan. News 2018, 44, 8 .

80. Yigitcanlar, T. Smart city policies revisited: Considerations for a truly smart and sustainable urbanism practice. World Technopolis Rev. 2018, 7, 97-112.

81. Lara, A.; Costa, E.; Furlani, T.; Yigitcanlar, T. Smartness that matters: Comprehensive and human-centred characterisation of smart cities. J. Open Innov. Technol. Mark. Complex. 2016, 2, 8. [CrossRef]

82. Yigitcanlar, T.; Foth, M.; Kamruzzaman, M. Towards post-anthropocentric cities: Reconceptualising smart cities to evade urban ecocide. J. Urban Technol. 2019, 26, 147-152. [CrossRef]

83. Yigitcanlar, T.; Kamruzzaman, M. Does smart city policy lead to sustainability of cities? Land Use Policy 2018, 73, 49-58. [CrossRef]

84. Stone, J.; Ashmore, D.; Scheurer, J.; Legacy, C.; Curtis, C. Planning for disruptive transport technologies: How prepared are Australian transport agencies? In Governance of the Smart Mobility Transition; Emerald: London, UK, 2018; pp. 123-137.

85. Cavoli, C.; Phillips, B.; Cohen, T.; Jones, P. Social and Behavioural Questions Associated with Automated Vehicles a Literature Review; UK Department for Transport: London, UK, 2017.

86. Zakharenko, R. Self-driving cars will change cities. Reg. Sci. Urban Econ. 2016, 61, 26-37. [CrossRef]

87. Corey, K.; Wilson, M. Urban and Regional Technology Planning; Routledge: London, UK, 2006.

88. Bell, D.R.; Gallino, S.; Moreno, A. The store is dead-Long live the store. MIT Sloan Manag. Rev. 2018, $59,59-66$.

89. Meyer, J.; Becker, H.; Bösch, P.M.; Axhausen, K.W. Autonomous vehicles: The next jump in accessibilities? Res. Transp. Econ. 2017, 62, 80-91. [CrossRef] 
90. Milakis, D.; Snelder, M.; Van Arem, B.; Van Wee, B.; De Almeida Correia, G.H. Development and transport implications of automated vehicles in the Netherlands: Scenarios for 2030 and 2050. Eur. J. Transp. Infrastruct. Res. 2017, 17, 63-85.

91. Soteropoulos, A.; Berger, M.; Ciari, F. Impacts of automated vehicles on travel behaviour and land use: An international review of modelling studies. Transp. Rev. 2019, 39, 29-49. [CrossRef]

(C) 2019 by the authors. Licensee MDPI, Basel, Switzerland. This article is an open access article distributed under the terms and conditions of the Creative Commons Attribution (CC BY) license (http://creativecommons.org/licenses/by/4.0/). 